\section{Kidney \\ Blood Pressure \\ Research}

Kidney Blood Press Res 2015;40:41-51

DOI: 10.1159/000368481

Published onlıne: February 10, 2015

(C) 2015 S. Karger AG, Base

www.karger.com/kbr

$1423-0143 / 15 / 0401-0041 \$ 39.50 / 0$

This is an Open Access article licensed under the terms of the Creative Commons Attribution-

NonCommercial 3.0 Unported license (CC BY-NC) (www.karger.com/OA-license), applicable to

the online version of the article only. Distribution permitted for non-commercial purposes only.

\title{
Induction of Apoptosis by Hypertension Via Endoplasmic Reticulum Stress
}

\author{
Yingying Sun ${ }^{\mathrm{a}} \quad$ Tong Zhang $^{\mathrm{b}} \quad \mathrm{Li} \mathrm{Li}^{\mathrm{a}} \quad$ Ji Wanga \\ aDepartment of ICU, China MeiTan General Hospital, 100028; 'Xi Yuan Hospital, China Academy of \\ Chinese Medical Sciences, 100091, Beijing, China
}

\author{
Key Words \\ Apoptosis • Caspase-12 • CHOP • ER stress • GRP78 • Hypertension
}

\begin{abstract}
Background/Aims: Endoplasmic reticulum (ER) stress is one of the intrinsic apoptosis pathways, and cardiac apoptosis can occur in cardiovascular diseases, such as hypertension. However, the mechanisms by which ER stress leads to apoptosis remain enigmatic, particularly in the progression from cardiac hypertrophy to diastolic heart failure due to hypertension. Methods: We used spontaneously hypertensive rats (SHRs) to investigate possible signalling pathways for ER stress. Results: We found that cardiac protein and mRNA levels of glucoseregulated protein 78 were up-regulated. In addition, the CHOP- and caspase-12-dependent pathways, but not that of JNK, were activated in the SHR rats. Conclusions: These results suggest that ER stress can contribute to myocardial apoptosis during hypertensive disease.
\end{abstract}

Copyright $@ 2015$ S. Karger AG, Basel

\section{Introduction}

The endoplasmic reticulum (ER) fulfils multiple cellular functions. Various conditions, such as ischemia, hypoxia, heat shock, gene mutations, and elevated protein synthesis, can disturb ER functions and result in ER stress $[1,2]$. In response to this type of stress, there is a marked upregulation of ER chaperones, such as glucose-regulated proteins 78 and 94 (GRP78, GRP94) and calreticulin [1, 3, 4]. Excessive and prolonged ER stress triggers cell suicide.

Apoptosis is a major contributor to cell loss during heart failure [5, 6]. It is well known that left ventricular hypertrophy (LVH) commonly occurs in hypertensive patients, and heart failure is the most frequent cause of death in these patients. Emerging data now indicate that apoptosis occurs in critical organs (heart, brain, or kidney) during hypertension [7- 


\section{Kidney \\ Blood Pressure Research}

Kidney Blood Press Res 2015;40:41-51

\begin{tabular}{l|l}
\hline DOI: $10.1159 / 000368481$ & C 2015 S. Karger AG, Basel
\end{tabular}

Published onlıne: February 10, 2015

www.karger.com/kbr

Sun/Zhang/Li/Wang: ER Stress in Hypertensive Myocardial Apoptosis

9]. However, the mechanisms by which ER stress leads to apoptosis remain enigmatic, particularly in the progression from cardiac hypertrophy to diastolic heart failure due to hypertension. Therefore, we hypothesised that ER stress may contribute to cardiac apoptosis, which is observed in this progression. To test this hypothesis, we examined the potential role of ER stress-induced apoptosis in spontaneously hypertensive rats (SHRs) and Wistar-Kyoto (WKY) rats.

\section{Materials and Methods}

\section{Preparation of the animal model}

This study was carried out in accordance with institutional guidelines for the experimental use of animals. The protocol was approved by the committee on the Ethics of Animal Experiments of the China MeiTan General Hospital and Xi Yuan Hospital. All of the surgeries were performed under sodium pentobarbital anaesthesia, and all efforts were made to minimise suffering. A total of 30 SHRs (8 weeks old, SPF, male) and 30 WKY rats ( 8 weeks old, SPF, male) were obtained from Vital River Laboratories. The rats were housed in cages with free access to the standard rat diet and tap water provided by the centre. The animals were maintained under standard lighting (alternating $12 \mathrm{~h} \mathrm{light/dark} \mathrm{cycle),} \mathrm{temperature}$ $\left(22 \pm 0.5^{\circ} \mathrm{C}\right)$ and humidity $(60 \pm 10 \%)$ conditions for at least 1 week before the experiments. Then, at the ages of 8, 16 or 32 weeks, ten SHRs or ten WKY rats were randomly killed in each group. The blood pressure of the rats was measured in the caudal artery using RBP-1 determination and analysis. The blood pressure was measured in each rat every 2 weeks.

\section{Echocardiographic evaluation}

Before sacrifice, each rat was anaesthetised with ketamine $\mathrm{HCl}(50 \mathrm{mg} / \mathrm{kg})$ and xylazine $(10 \mathrm{mg} / \mathrm{kg})$ and placed in the left lateral decubitus position. The chest of the rat was shaved, and a layer of acoustic coupling gel was applied to the thorax. Two-dimensional and M-mode echocardiography was performed using a commercially available 12-MHz linear-array transducer system and an echocardiogram (Sonos 5500, HP, MA). M-mode recordings were obtained of the left ventricle at the level of the mitral valve in the parasternal view using two-dimensional echocardiographic guidance in both the short and long axis views. Pulsed-wave Doppler was used to examine mitral diastolic inflow from the apical four-chamber view. For each measurement, data from three consecutive cardiac cycles were averaged. All of the measurements were made from digital images captured at the time of the study by use of inherent analysis software (Sonos 5500 software package).

Terminal deoxynucleotidyl transferase-mediated DNA nick-end labelling (TUNEL) staining

Rat hearts were transversally sliced and fixed in $4 \%$ neutral buffered formalin for over $24 \mathrm{~h}$, followed by embedding in paraffin. The hearts were sectioned at a thickness of $5 \mu \mathrm{m}$ and analysed with the TUNEL assay kit (catalogue number KGA703, Keygen Biotechnology, China). The sections were deparaffinised, digested with proteinase $\mathrm{K}(20 \mathrm{\mu g} / \mathrm{ml})$ at room temperature for $15 \mathrm{~min}$, and soaked in phosphate buffer saline (PBS) for $5 \mathrm{~min}$. Each section was covered with a terminal deoxynucleotidyl transferase (TDT) enzyme solution containing $45 \mu \mathrm{l}$ equilibration buffer, $1 \mu \mathrm{l}$ biotin-ll-dUTP, and $4 \mu \mathrm{l}$ TDT enzyme and incubated for $1 \mathrm{~h}$ at $37^{\circ} \mathrm{C}$ in a humidified chamber. The sections were immersed in stop buffer to terminate the enzymatic reaction and then gently rinsed with PBS. A 50- $\mu$ l streptavidin-horseradish peroxidase (HRP) solution (0.25 $\mu \mathrm{l}$ streptavidin-HRP, $49.75 \mu \mathrm{l}$ PBS) was then applied to each section, and the sections were incubated at room temperature for $30 \mathrm{~min}$ in the dark. The slides were washed in PBS, exposed for 5-7 min to diaminobenzidine $(D A B) \pm$ chromogen. Then, the sections were examined using light microscopy. Sections incubated with PBS instead of the TDT enzyme solution served as negative controls. The number of TUNEL-positive cells was counted in five randomly selected fields of view under $400 \times$ magnification per animal, and ten animals were studied per group. All studies were performed by an observer who was blinded to the study groups to which the animals were assigned. 


\section{Kidney \\ Blood Pressure Research}

Kidney Blood Press Res 2015;40:41-51

\begin{tabular}{l|l}
\hline DOI: $10.1159 / 000368481$ & C 2015 S. Karger AG, Basel
\end{tabular}

Published online: February 10, 2015

www.karger.com/kbr

Table 1. The sequence for each primer and amplification conditions

\begin{tabular}{|c|c|c|c|}
\hline & Primer sequences $\left(5^{\prime}-3^{\prime}\right)$ & $\begin{array}{c}\text { Annealing } \\
\text { temperature }\left({ }^{\circ} \mathrm{C}\right)\end{array}$ & $\begin{array}{l}\text { Length } \\
\text { (bp) }\end{array}$ \\
\hline \multirow[t]{2}{*}{ GRP78 } & F AACCCAGATGAGGCTGTAGCA & 57 & 91 \\
\hline & R ACATCAAGCAGAACCAGGTCAC & & \\
\hline \multirow[t]{2}{*}{ CHOP } & F CCAGCAGAGGTCACAAGCAC & 56 & 126 \\
\hline & R CGCACTGACCACTCTGTTTC & & \\
\hline \multirow[t]{2}{*}{ p-JNK } & F TGATGACGCCTTACCTGGTA & 54 & 114 \\
\hline & R GGCAAACCATTTCTCCCATA & & \\
\hline \multirow[t]{2}{*}{ caspase- 12} & F CACTGCTGATACAGATGAGG & 56 & 138 \\
\hline & R CСАСТСТTGCСТАССТTCC & & \\
\hline \multirow[t]{2}{*}{$\beta$-actin } & F TGTTGCCCTAGACTTCGAGCA & 59 & 155 \\
\hline & R GGACCCAGGAAGGAAGGCT & & \\
\hline
\end{tabular}

Real-time PCR analysis

Total RNA was isolated from hearts using Trizol reagent (Invitrogen, USA) according to the manufacturer's instructions. The reverse transcription of RNA to cDNA was performed using reverse transcriptase (Promega, Madison, Wisconsin) at $37^{\circ} \mathrm{C}$ for $1 \mathrm{~h}$. cDNA was amplified with Light-CyclerFastStart DNA Master SYBR Green I (TaKaRa Biotechnology). The primer sequences for rat GRP78, CHOP, caspase-12, p-JNK, $\beta$-actin are listed in Table 1 . After an initial denaturation step of $10 \mathrm{~s}$ at $95^{\circ} \mathrm{C}, 45 \mathrm{cycles}$ of the following temperature steps were performed: denaturation at $95^{\circ} \mathrm{C}$ for $0 \mathrm{~s}$, annealing at $54-59^{\circ} \mathrm{C}$ for $5 \mathrm{~s}$ and extension at $72^{\circ} \mathrm{C}$ for $10 \mathrm{~s}$. A melting-curve was then generated at $65^{\circ} \mathrm{C}$ for $30 \mathrm{~s}$. At the end of each cycle, the fluorescence emitted by the SYBR Green I dye was measured. The specificity of products generated for each set of primers was examined for each fragment using the melting curve and gel electrophoresis. The relative expression levels of each targeted gene were normalised by subtracting the corresponding $\beta$-actin threshold cycle (CT) values using the $\Delta \Delta$ CT comparative method. A total of ten samples for each group were used for real-time PCR, and each sample was run in triplicate.

\section{Western blot analysis}

Tissue samples from the hearts were homogenised in a lysis buffer $(0.1 \mathrm{~mol} / \mathrm{l} \mathrm{NaCl}, 0.01 \mathrm{M}$ Tris$\mathrm{HCl}$, PH 7.5, $1 \mathrm{mM}$ EDTA, and $1 \mu \mathrm{g} / \mathrm{ml}$ Aprotinin), and the homogenates were then centrifuged at $7000 \mathrm{~g}$ for $15 \mathrm{~min}$ at $4^{\circ} \mathrm{C}$. The supernatants were used as protein samples. We used the Bradford assay (Bio-Rad Laboratories, Hercules, CA) to determine the protein concentrations for each sample. Western blot analysis was performed with a 5\% acrylamide stacking gel and a 14\% acrylamide resolving gel; $60 \mu \mathrm{g}$ of protein was subjected to gel electrophoresis. The proteins were then transferred from the gel to nitrocellulose membranes (LC2006, Invitrogen, CA) at $120 \mathrm{~V}$ for $50 \mathrm{~min}$. Nonspecific protein binding to the nitrocellulose membrane was reduced by pre-incubating the membrane with blocking buffer (5\% nonfat dry milk, 2.7 $\mathrm{mM} \mathrm{KCl}, 137 \mathrm{mM} \mathrm{NaCl}, 8 \mathrm{mM} \mathrm{Na} 2 \mathrm{HPO} 4,1.4 \mathrm{mM} \mathrm{KPO} 4$ and $0.1 \%$ Tween 20) for $2 \mathrm{~h}$ at room temperature. Incubations were performed overnight at $4^{\circ} \mathrm{C}$ with the following monoclonal antibodies: anti- $\beta$-actin (1:1000 diluted in blocking buffer, Zhongshan Golden Bridge Biotechnology, China), anti-GRP78 (1:500, SC-1611, Santa Cruz, CA), anti-CHOP (1:600, SC-7531, Santa Cruz, CA), anti-caspase-12 (1:500, SC-1050, Santa Cruz, CA), anti-p-JNK (1:400, SC-6254, Santa Cruz, CA), anti-JNK (1:1000, SC-81468, Santa Cruz, CA) and anti-cleaved-caspase-3 (1:500, SC-7148, Santa Cruz, CA). The membranes were then incubated with secondary antibodies (anti-goat, anti-rabbit, anti-rat and anti-mouse IgG conjugated to HRP, in blocking buffer 1:1000, Zhongshan Golden Bridge Biotechnology, China) for $2 \mathrm{~h}$ at room temperature. The reaction was visualised by chemiluminescence (Enhanced Chemiluminescent Kit, ECL, UK). The film was scanned with an imaging densitometer (FluorChem HD IS-9900, Alpha, CA), and the optical density was quantified using Multi-Analyst software. 


\section{Kidney \\ Blood Pressure Research}

Table 2. Echoardiographic data

\begin{tabular}{lcccccc}
\hline & \multicolumn{2}{c}{8 weeks } & \multicolumn{2}{c}{16} & weeks & \multicolumn{2}{c}{ weeks } \\
\cline { 2 - 7 } & WKY rats & SHRs & WKY rats & SHRs & WKY rats & SHRs \\
\hline Interventricular & $2.10 \pm 0.04$ & $1.97 \pm 0.06$ & $2.25 \pm 0.05$ & $2.64 \pm 0.91^{*}$ & $2.34 \pm 0.49$ & $2.78 \pm 0.08^{*}$ \\
septum, mm & & & & & & \\
Posterior wall,mm & $1.7 \pm 0.07$ & $2.4 \pm 0.16^{*}$ & $1.8 \pm 0.07$ & $2.4 \pm 0.24^{*}$ & $2.0 \pm 0.09$ & $2.62 \pm 0.11^{*}$ \\
E/A & $1.57 \pm 0.11$ & $1.49 \pm 0.06$ & $1.65 \pm 0.09$ & $1.38 \pm 0.04$ & $1.42 \pm 0.68$ & $2.46 \pm 0.20^{*}$ \\
IVRT,ms & $24.95 \pm 0.53$ & $25.26 \pm 0.6$ & $26.45 \pm 0.9$ & $31.79 \pm 0.94^{*}$ & $28.42 \pm 0.7$ & $29.94 \pm 0.69$ \\
FS(\%) & $47.39 \pm 0.84$ & $47.18 \pm 0.7$ & $48.77 \pm 0.5$ & $48.12 \pm 0.89$ & $49.03 \pm 0.7$ & $48.85 \pm 0.84$ \\
EF(\%) & $71.44 \pm 0.76$ & $71.58 \pm 0.8$ & $72.43 \pm 1.0$ & $72.59 \pm 0.79$ & $72.87 \pm 1.1$ & $71.77 \pm 1.02$ \\
\hline
\end{tabular}

Data are shown as mean \pm SEM. E: peak early transmitral filling velocity during early diastole; A: peak transmitral atrial filling velocity during late diastole. IVRT: isovolumic relaxation time. EF: ejection fraction; FS: fractional shortening. Ten animals were studied per group. ${ }^{*} P<0.05$ vsWKY rats

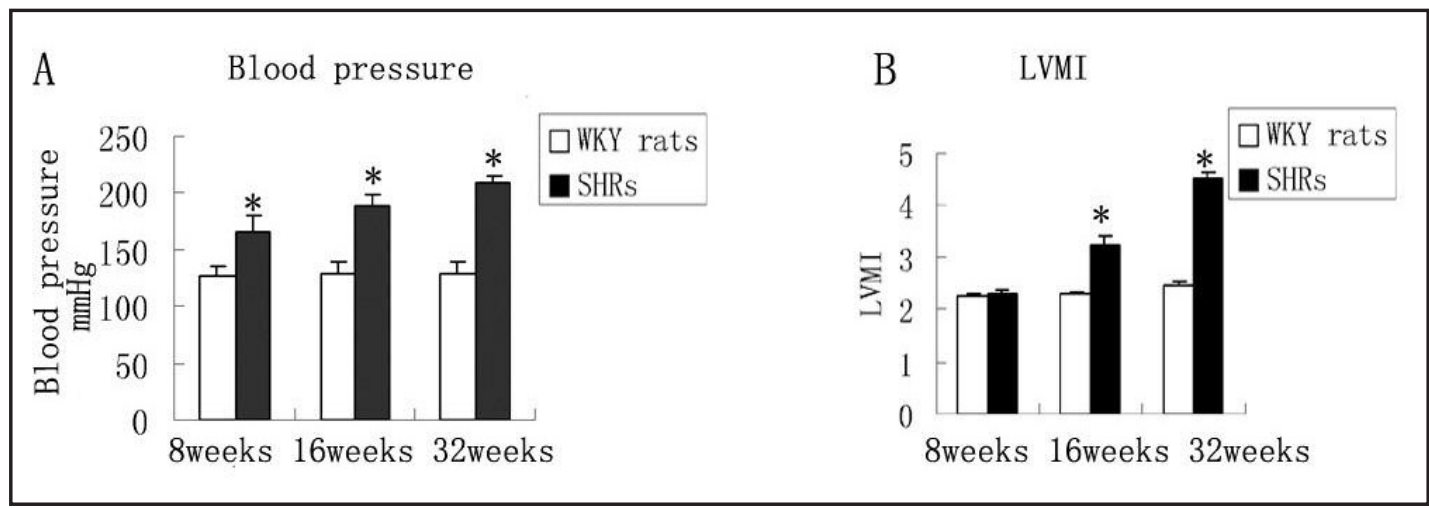

Fig. 1. A, Blood pressure. Blood pressure levels in the SHRs have shown a significant raise at 8 weeks old, and continued to 32 weeks old compared with the WKY rats. B, LVMI. LVMI=left ventricular mass (LVM, $\mathrm{mg}$ )/body mass (BM, g). Ten animals were studied per group. ${ }^{*} P<0.05$ vs WKY rats, ${ }^{\#} P<0.01$ vs WKY rats.

\section{Statistical analysis}

The experimental data were analysed using SPSS 17 software in Windows XP. All of the results are expressed as the mean \pm SEM. The individual groups were tested for differences using one-way repeatedmeasurement ANOVA followed by independent sample t-tests. Differences were considered statistically significant at $P<0.05$.

\section{Results}

Establishment of the model

The blood pressure and left ventricular mass index (LVMI, LVMI=left ventricular mass (LVM, mg)/body mass (BM, g)) differed significantly in SHRs compared to the control WKY rats (Fig.1). The echocardiographic data are shown in Table 2. The left ventricular diastolic function variables, expressed by the ratio of the E-wave (early diastolic filling, early peak velocity) to the A-wave (late atrial filling, atrial peak velocity), differed significantly $(P<0.05)$ in SHRs $(32$ weeks) compared to those of WKY rats (32 weeks). A significant increase in the E-wave velocity, a significant decrease in the A-wave velocity, and a remarkable increase in the E/A ratio were observed (E/A $>>2$ ). The left ventricular systolic function parameters, fractional shortening (\%), and ejection fraction (\%) of the SHRs were not significantly different compared to the WKY rats (32 weeks). Furthermore, the interventricular septum, posterior wall and LVMI also 


\section{Kidney Blood Pressure Research}

differed significantly $(P<0.05) \quad$ compared to those of WKY rats at 16 weeks. These results demonstrated that SHRs exhibited cardiac hypertrophy at 16 weeks of age and diastolic heart failure at 32 weeks of age.

The localisation of apoptosis by the TUNEL assay

To assess whether cardiac myocyte apoptosis occurs in the hypertensive heart, the tissue sections were labelled using a TUNEL assay (Fig. 2). Apoptosis was observed in both the cardiocytes and endothelium of the hypertensive heart. More apoptotic cardiocytes were observed in the SHR (16 weeks and 32 weeks) groups. An estimation of cardiac apoptosis revealed a nearly threefold increase in TUNEL-positive nuclei in the hypertensive heart.

\section{Real-time $\quad P C R$ verification of the upregulation \\ of ER stress- \\ associated genes}

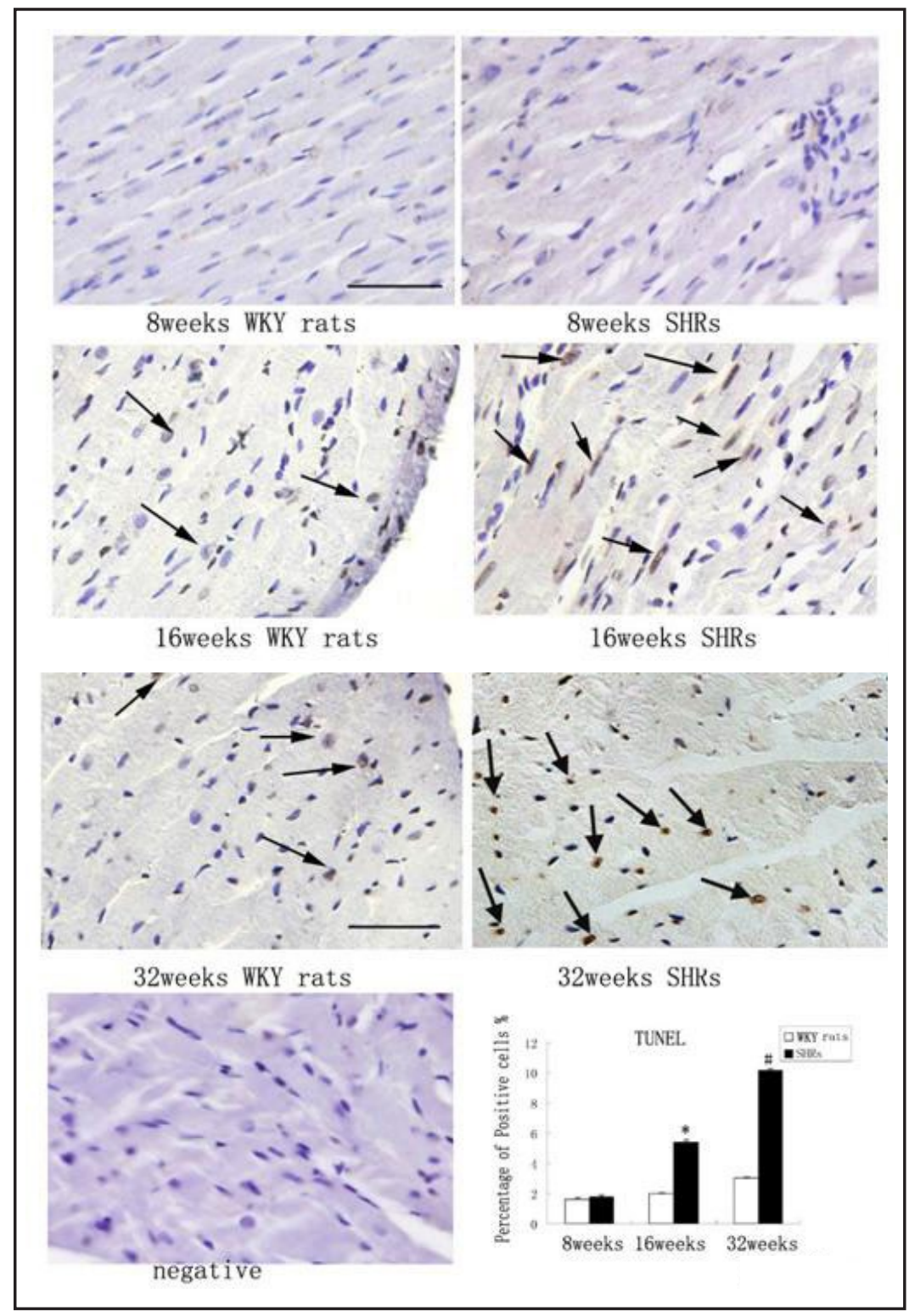

Fig. 2. TUNEL staining of apoptotic bodies (arrows point). Compared with the normal heart, the hypertensive heart has notably higher positive expression. Ten animals were studied per group. ${ }^{*} P<0.05$ vs WKY rats, ${ }^{\sharp} P<0.01$ vs WKY rats. Bar $=20 \mu \mathrm{m}(40 \times)$.

The mRNA levels of ER stress-associated genes were measured by quantitative realtime PCR. During the initial stage of hypertension, only the mRNA levels of GRP78 and CHOP were upregulated. The mRNA levels of GRP78, CHOP, and caspase-12, but not p-JNK, were found to be significantly $(P<0.05)$ upregulated in both hypertrophic rats and those with diastolic heart failure. Similar levels of p-JNK mRNA were observed in all hypertensive and normal rats (Fig. 3).

Immunoblot analysis of ER stress-associated proteins

We detected GRP78, CHOP and cleaved-caspase-3 proteins in rat myocardia using 


\section{Kidney \\ Blood Pressure \\ Research}

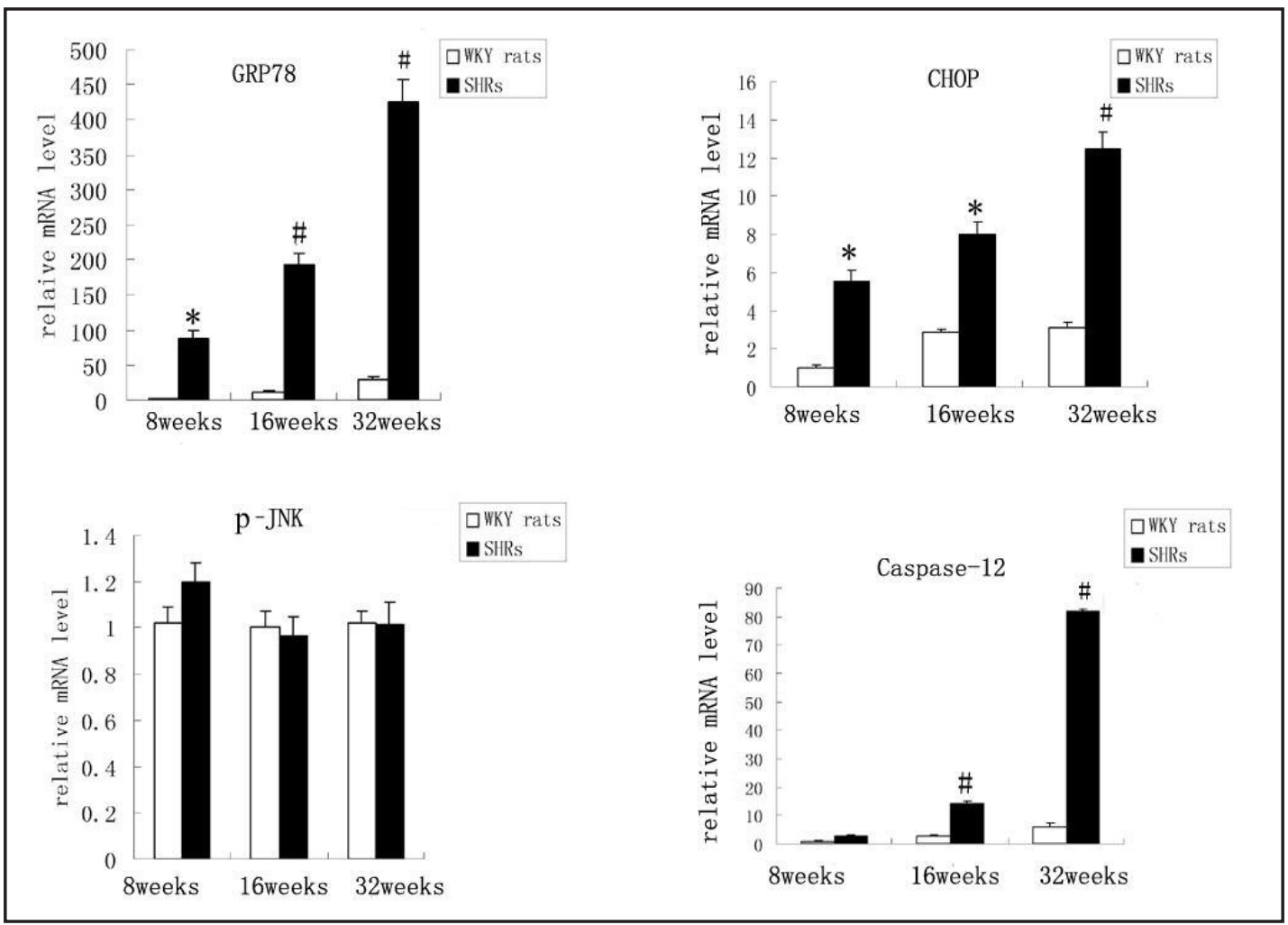

Fig. 3. Upregulation of the ER stress associated genes. Total RNA was extracted from myocardium and subjected to real-time PCR quantification as described under materials and methods. Quantitative analysis of the ER stress-associated genes in rat hearts. Ten animals were studied per group. ${ }^{*} P<0.05$ vs WKY rats, ${ }^{\#} P<0.01$ vs WKY rats.

western blots. These proteins were detected as single bands that migrated distances indicating sizes of $78 \mathrm{kDa}, 26 \mathrm{kDa}$ and $17 \mathrm{kDa}$, respectively. Two bands between 30 and 50 $\mathrm{kDa}$ were observed for caspase-12, and two bands between 46 and $54 \mathrm{kDa}$ were observed for p-JNK and JNK. Consistent with the mRNA levels, during the initial stage of hypertension, only the protein levels of GRP78 and CHOP were upregulated. The densitometric analysis of bands for GRP78, CHOP, and caspase-12, but not JNK or p-JNK, revealed a significant $(P<0.05)$ increase in the relative protein content in the myocardium of SHRs (16 weeks and 32 weeks) compared to WKY rats. These protein levels were markedly increased in the hypertensive heart and coincided with the appearance of apoptosis (caspase-3 cleavage) (Fig. 4).

\section{Discussion}

The ER is a highly dynamic organelle that participates in folding secretory and membrane proteins. To address the enhanced synthesis of secretory proteins when the ER is overloaded, molecular compensatory mechanisms 1) upregulate ER chaperones; 2) reduce translation, decreasing the load of new protein synthesis, and 3) degrade misfolded proteins within the ER [10]. When ER stress conditions persist, the initiation of apoptotic processes is promoted by the transcriptional induction of C/EBP homologous protein (CHOP/GADD153) [11], the caspase-12-dependent pathway [12], and activation of the c-Jun NH2-terminal kinase (JNK)-dependent pathway [13].

Several signalling pathways are initiated to manage ER stress, and this effect is known as the unfolded protein response (UPR) [14]. One major pathway of the UPR increases the 


\section{Kidney \\ Blood Pressure \\ Research}

Kidney Blood Press Res 2015;40:41-51

DOI: $10.1159 / 000368481$

Publisned online: February 10, 2015

(C) 2015 S. Karger AG, Basel

www.karger.com/kbr

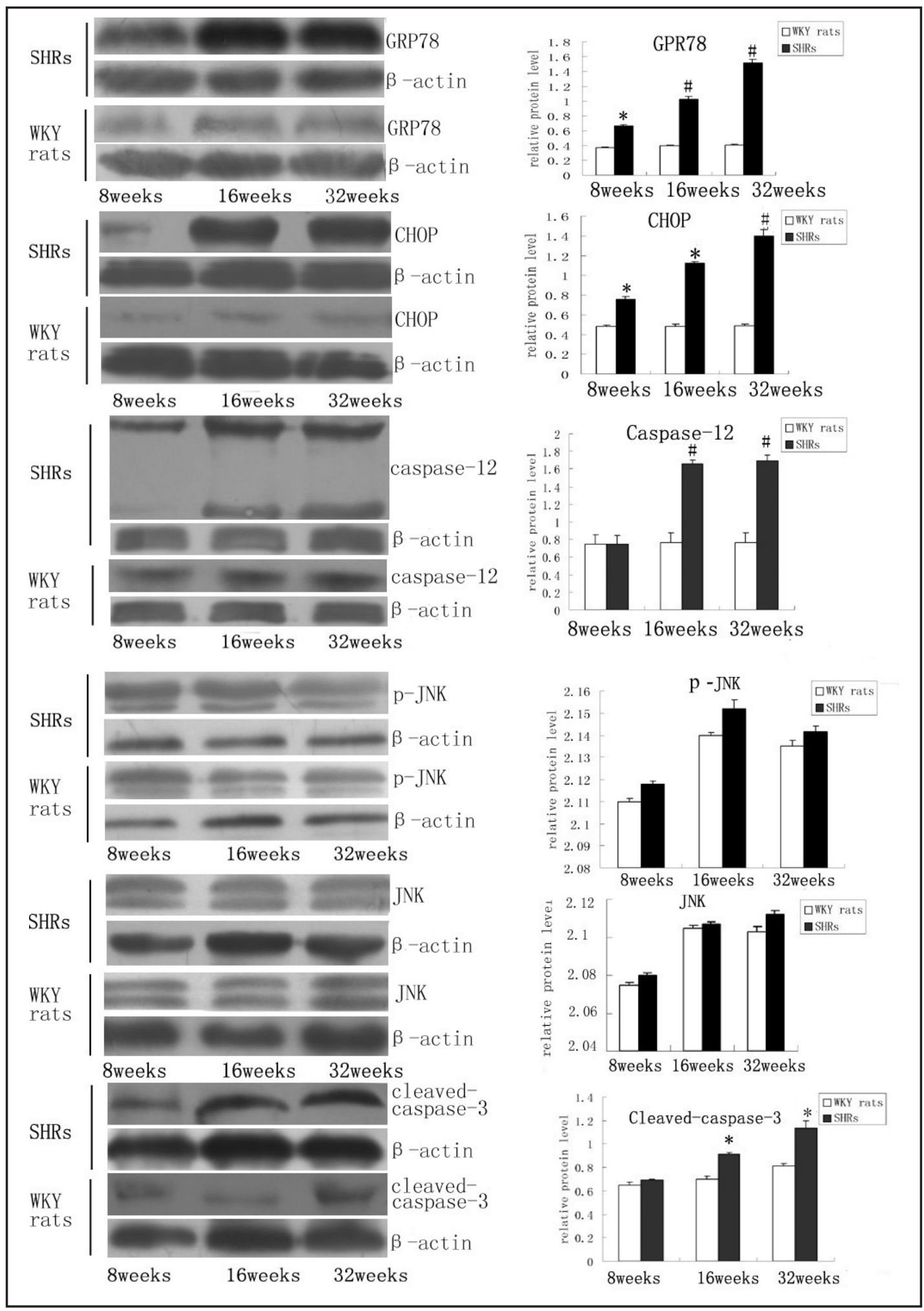

Fig. 4. Upregulation of the ER stress-associated proteins. Protein levels of GRP78, CHOP, JNK, p-JNK, caspase-12 and cleaved-caspase- 3 in rats hearts and quantitative analysis of the ER stress-associated proteins in rat hearts. Ten animals were studied per group. ${ }^{*} P<0.05$ vs WKY rats, ${ }^{*} P<0.01$ vs WKY rats. 


\section{Kidney Blood Pressure Research}

Kidney Blood Press Res 2015;40:41-51

\begin{tabular}{l|l}
\hline DOI: 10.1159/000368481 & $\begin{array}{l}\text { C 2 2015 S. Karger AG, Basel } \\
\text { www.karger.com/kbr }\end{array}$
\end{tabular}

Publisned onlıne: February 10, 2015

Sun/Zhang/Li/Wang: ER Stress in Hypertensive Myocardial Apoptosis

expression of ER-localised molecular chaperones, such as GRP78, which can contribute to repairing unfolded proteins. The induction of GRP78 has been widely used as a marker for ER stress and initiation of the UPR [12]. Furthermore, GRP78 serves as a master modulator for the UPR network by binding to the ER stress sensors, including PKR-like ER kinase (PERK), inositol requiring 1 (IRE1), and transcription factor 6 (ATF6), inhibiting their activation [15]. In the present study, the mRNA and protein levels of GRP78 were markedly upregulated in the hypertensive heart. This finding suggests that hypertension actives ER stress in the rat heart. Increased GRP78 has been reported in ER stress-associated apoptosis in decidual cells [16] and in renal proximal tubular cells [17], in synchronous multiple primary cancers in the oesophagus and stomach [18], in diabetic cardiomyopathy [19], and in mineralising tissues and mesenchymal cells [20].

However, TUNEL-positive cells were not observed during the initial stage of hypertension. We propose that during the preliminary stage of hypertension, the ER only switches on the UPR to block these stresses. The UPR allows the cells to adjust to the altered environment and reinstate normal ER functions. These adaptive mechanisms involve transcriptional programs that induce gene expression that enhances the protein folding capacity of the ER and promote ER-associated protein degradation to remove misfolded proteins [21].

Emerging data have indicated that when ER stress is excessive and/or prolonged, the initiation of apoptotic processes is promoted by the transcriptional induction of CHOP or by the activation of JNK and/or the caspase-12-dependent pathway [22]. The main components of these pathways include the following. (1) CHOP/GADD153: CHOP is a member of the C/ EBP family of bZIP transcription factors, and its expression is strongly induced by ER stress [23]. CHOP expression can be attributed to the activity of IRE1, PERK and ATF6, and CHOP protein overexpression induces apoptosis through a Bcl-2-inhibitable mechanism [23]. (2) JNK: JNK belongs to the stress-activated protein kinases and has been shown to induce apoptosis in response to ER stress [3, 22]. JNK-mediated phosphorylation activates the proapoptotic protein Bim [24]. (3) Caspase-12: caspases are required for apoptosis, and certain members of this family of cysteine proteases associate with the ER [25]. In rodents, caspase-12 associates with activated IRE1, resulting in proteolytic processing of caspase-12. Activated caspase- 12 can trigger caspase- 9 , and procaspase- 3 can be cleaved by activated caspase-9. Activated caspase-3 causes apoptosis. Recent work has supported a central role for the caspase family of cysteine proteases, especially caspase-3, as effectors of apoptosis [26].

Long-term hypertension has been shown to be an effective stimulus for cardiocyte apoptosis [27]. In our experiment, the number of TUNEL-positive cardiac myocytes was significantly increased in failing hearts, and CHOP, caspase-12, and caspase-3, but not JNK, were simultaneously induced. CHOP is a transcription factor that is expressed at low levels under homeostatic conditions and strongly induced by a variety of signals that lead to ER stress [28]. Caspase-12 is located on the ER membrane and is activated only by ER stress $[3,16,21]$. CHOP and Caspase-12 are induced at the transcriptional and translational levels when the ER is stressed. Although the CHOP- and caspase-12-dependent pathways were activated in hypertrophic hearts and in those undergoing diastolic failure, more TUNELpositive cells were found in the 32-week SHR group than in the 16-week group, which was consistent with the protein levels of cleaved-caspase-3 and CHOP. This increased prevalence of apoptotic cells was also observed in the mesenteric small resistance arteries of SHRs [29]. We speculate that in addition to ER stress-associated apoptosis, many other apoptotic mechanisms may participate in the development and progression of diastolic heart failure. It is known that two evolutionarily conserved central death pathways mediate apoptosis: the extrinsic pathway, which utilises cell surface death receptors, and the intrinsic pathway, which involves mitochondria and the ER [30]. Relevant stimuli in heart failure most likely include stretch, angiotensin II, ROS, $\beta 1$-adrenergic agonists, proinflammatory cytokines, cytoskeletal abnormalities, and drugs [31]. Li Z et al have shown that chronic pressure overload or genetic predisposition can stimulate a cell growth and/or repair response that 


\section{Kidney \\ Blood Pressure Research}

triggers apoptosis in the SHR myocardium [32]. In chronically pressure-loaded myocardium, the balance between cell damage and repair was shifted toward cell suicide [32]. In 1995, Hamet et al demonstrated that the remodelling of cardiovascular tissues represented an imbalance between cell proliferation and apoptosis and that rarefaction might be a consequence of apoptosis associated with hypertension [33]. The mechanisms of heightened susceptibility to apoptosis might involve TGF- $\beta 1$, TNF- $\alpha$, cAMP, or other pathways [33]. Furthermore, the apoptotic response to angiotensin II was higher in SHR cardiocytes than in WKY cardiocytes [34], and angiotensin II-induced cardiac apoptosis was associated with increased Bax expression and caspase-3 activation [35].

Recent studies have also demonstrated that apoptosis in cardiocytes is linked to ER stress. Studies in transverse aortic constriction (TAC) mice have demonstrated that pressure overload by TAC induces prolonged ER stress, which contributes to cardiac myocyte apoptosis during the progression from cardiac hypertrophy to heart failure [36]. Studies in the hearts of MCP mice (transgenic mice that express MCP-1 specifically in the heart) strongly suggest that activation of the ER stress response is involved in the development of ischemic heart disease [37]. Studies of the mutant KDEL receptor, which sensitises cells to ER stress, have demonstrated a disturbance in ER quality control that resulted in the accumulation of misfolded proteins in the ER in an in vivo system. In transgenic mice with dilated cardiomyopathy, the mutant KDEL receptor is associated with ER stress [38].

Our study has demonstrated that molecular chaperones of the ER are upregulated and apoptosis pathways of ER stress are activated during the progression from cardiac hypertrophy to diastolic heart failure due to hypertension. In conclusion, we can assume that a persistent hypertensive condition will continuously activate ER stress.

\section{Conclusion}

If it was possible to effectively prevent cell death due to ER stress, the occurrence of LVH could be delayed, reducing damage to critical organs. Further investigation of the intracellular signalling and importance of ER stress-induced apoptosis in the hypertensive heart is needed.

\section{Disclosure Statement}

The authors of this manuscript state that they do not have any conflict of interests and nothing to disclose.

\section{Acknowledgments}

We would like to thank Mr. Luowen $\mathrm{Hu}, \mathrm{Mrs}$. Ou Li, and Mr. Rui Ma for the technical work associated with this research.

\section{References}

1 Kaufman RJ: Stress signaling from the lumen of the endoplasmic reticulum: coordination of gene transcriptional and translational controls. Genes Dev 1999;13:1211-1233.

-2 Ron D: Translational control in the endoplasmic reticulum stress response. J Clin Invest 2002;110:1383-1388. 


\section{Kidney \\ Blood Pressure Research}

Kidney Blood Press Res 2015;40:41-51

\begin{tabular}{l|l}
\hline DOI: $10.1159 / 000368481$ & C 2015 S. Karger AG, Basel
\end{tabular}

Published online: February 10, 2015

www.karger.com/kbr

3 Wong DP, Chu JM, Hung VK, Lee DK, Cheng CH, Yung KK, Yue KK: Modulation of endoplasmic reticulum chaperone GRP78 by high glucose in hippocampus of streptozotocin-induced diabetic mice and C6 astrocytic cells. Neurochem Int 2013;63:551-560.

4 Lind KR, Ball KK, Cruz NF, Dienel GA: The unfolded protein response to endoplasmic reticulum stress in cultured astrocytes and rat brain during experimental diabetes. Neurochem Int 2013;62:784-795.

5 Takemura G, Kanoh M, Minatoguchi S, Fujiwara H: Cardiomyocyte poptosis in the failing heart-a critical review from definition and classification of cell death. Int J Cardiol 2013;167:2373-2386.

6 Wencker D, Chandra M, Nguyen K, Miao W, Garantziotis S, Factor SM, Shirani J, Armstrong RC, Kitsis RN: A mechanistic role for cardiac myocyte apoptosis in heart failure. J Clin Invest 2003;111:14971504.

7 Lin PP, Hsieh YM, Kuo WW, Lin YM, Yeh YL, Lin CC, Tsai FJ, Tsai CH, Huang CY, Tsai CC: Probioticfermented purple sweet potato yogurt activates compensatory IGF IR/PI3K/Akt survival pathways and attenuates cardiac apoptosis in the hearts of spontaneously hypertensive rats. Int J Mol Med 2013;32:1319-1328.

8 Jiang T, Gao L, Shi J, Lu J, Wang Y, Zhang Y: Angiotensin-(1-7) modulates renin-angiotensin system associated with reducing oxidative stress and attenuating neuronal apoptosis in the brain of hypertensive rats. Pharmacol Res 2013;67:84-93.

-9 Kanbak G, Uzuner K, Kuşat Ol K, Oğlakçı A, Kartkaya K, Şentürk H: Effect of kefir and low-dose aspirin on arterial blood pressure measurements an-d renal apoptosis inunhypertensive rats with 4 weeks salt diet. Clin Exp Hypertens 2014;36:1-8.

10 Jäger R, Bertrand MJ, Gorman AM, Vandenabeele P, Samali A: The unfolded protein response at the crossroads of cellular life and death during endoplasmic reticulum stress. Biol Cell 2012;104:259-270.

11 Liu X, Wang M, Chen H, Guo Y, Ma F, Shi F, Bi Y, Li Y: Hypothermia protects the brain from transient global ischemia/reperfusion by attenuating endoplasmic reticulum response-induced apoptosis through CHOP. PLoS One 2013;8:e53431.

$\checkmark 12$ Zhao S, Xiong Z, Mao X, Meng D, Lei Q, Li Y, Deng P, Chen M, Tu M, Lu X, Yang G, He G: Atmospheric pressure room temperature plasma jets facilitate oxidative and nitrative stress and lead to endoplasmic reticulum stress dependent apoptosis in HepG2 cells. PLoS One 2013;8:e73665.

13 He YY, He KL, Liu CL: Research of ER stress and cdiovascular diseases. Sheng Li Ke Xue Jin Zhan 2011;42:419-422.

14 Bernales S, Papa FR, Walter P: Intracellular signaling by the unfolded protein response. Annu Rev Cell Dev Biol 2006;22:487-508.

15 Schröder M, Kaufman RJ: The mammalian unfolded protein response. Annu Rev Biochem 2005;74:739-789.

16 Gao HJ, Zhu YM, He WH, Liu AX, Dong MY, Jin M, Sheng JZ, Huang HF: Endoplasmic reticulum stress induced by oxidative stress in decidual cells: a possible mechanism of early pregnancy loss. Mol Biol Rep 2012;39:9179-9186.

-17 Ohse T, Inagi R, Tanaka T, Ota T, Miyata T, Kojima I, Ingelfinger JR, Ogawa S, Fujita T, Nangaku M: Albumin induces endoplasmic reticulum stress and apoptosis in renal proximal tubular cells. Kidney Int 2006;70:1447-1455.

18 Wang R, Wang MJ, Yang JL, Tang CW: Upper gastrointestinal endoscopy detection of synchronous multiple primary cancers in esophagus and stomach: single center experience from china. Gastroenterol Res Pract 2012;2012:4323-4367.

-19 Zhenhua Li, Tao Zhang, Hongyan Dai, Guanghui Liu, Yingying Sun, Zhang Y, Ge Z: Involvement of Endoplasmic Reticulum Stress in Myocardial Apoptosis of Streptozocin-Induced Diabetic Rats. J Clin Biochem Nutr 2007;41:58-67.

20 Ravindran S, Gao Q, Ramachandran A, Sundivakkam P, Tiruppathi C, George A: Expression and distribution of grp-78/bip in mineralizing tissues and mesenchymal cells. Histochem Cell Biol Jul 2012;138:113-125.

-21 Xu C, Bailly-Maitre B, Reed JC: Endoplasmic reticulum stress: cell life and death decisions. J Clin Invest 2005;115:2656-2664.

-22 Tan Y, Dourdin N, Wu C, De Veyra T, Elce JS, Greer PA: Ubiquitous calpains promote caspase-12 and JNK activation during ER stress induced apoptosis. J Biol Chem 2006;281:16016-16024. 


\section{Kidney \\ Blood Pressure Research}

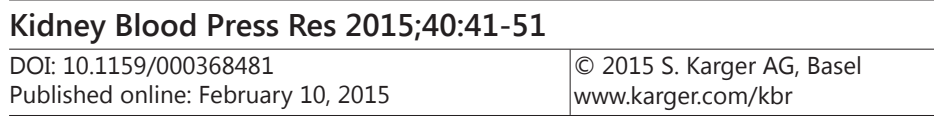

Sun/Zhang/Li/Wang: ER Stress in Hypertensive Myocardial Apoptosis

23 McCullough KD, Martindale JL, Klotz LO, Aw TY, Holbrook NJ: Gadd153 sensitizes cells to endoplasmic reticulum stress by downregulating Bcl2 and perturbing the cellular redox state. Mol Cell Biol 2001;21:1249-1259.

24 Lei K, Davis RJ: NK phosphorylation of Bim-related members of the Bcl-2 family induces Baxdependent apoptosis. Proc Natl Acad Sci USA 2003;100:2432-2437.

-25 Wu CT, Weng TI, Chen LP, Chiang CK, Liu SH: Involvement of caspase-12-dependent apoptotic pathway in ionic radiocontrast urografin induced renal tubular cell injury. Toxicol Appl Pharmacol 2013;266:167-175.

-26 Kim KW, Moretti L, Mitchell LR, Jung DK, Lu B: Endoplasmic reticulum stress mediates radiationinduced autophagy by perk-eIF2alpha in caspase-3/7-deficient cells. Oncogene 2010;29:3241-3251.

-27 Xu J, Carretero OA, Liao TD, Peng H, Shesely EG, Xu J, Liu TS, Yang JJ, Reudelhuber TL, Yang P: Local angiotensin II aggravates cardiac remodeling in hypertension. Am J Physiol Heart Circ Physiol 2010;299:H1328-H1338.

-28 Oyadomari S, Mori M: Roles of CHOP/GADD153 in endoplasmic reticulum stress. Cell Death Differ 2004;11:381-389.

29 Rizzoni D, Rodella L, Porteri E, Rezzani R, Guelfi D, Piccoli A, Castellano M, Muiesan ML, Bianchi R, Rosei EA: Time course of apoptosis in small resistance arteries of spontaneously hypertensive rats. J Hypertens 2000;18:885-891.

30 Danial NN, Korsmeyer SJ: Cell death: critical control points. Cell 2004;116:205-219.

31 Foo RS, Mani K, Kitsis RN: Death begets failure in the heart. J Clin Invest 2005;115:565-571.

-32 Li Z, Bing OH, Long X, Robinson KG, Lakatta EG: Increased cardiomyocyte apoptosis during the transition to heart failure in the spontaneously hypertensive rat. Am J Physiol 1997;272:H2313-H2319.

-33 Hamet P, Richard L, Dam TV, Teiger E, Orlov SN, Gaboury L, Gossard F, Tremblay J: Apoptosis in target organs in hypertension. Hypertension 1995;26:642-648.

-34 Ravassa S, Fortuño MA, González A, López B, Zalba G, Fortuño A, Díez J: Mechanisms of increased susceptibility to angiotensin II-induced apoptosis in ventricular cardiomyocytes of spontaneously hypertensive rats. Hypertension 2000;36:1065-1071.

-35 Diep QN, El Mabrouk M, Yue P, Schiffrin EL: Effect of AT(1) receptor blockade on cardiac apoptosis in angiotensin II-induced hypertension. Am J Physiol Heart Circ Physiol 2002;282:H1635-H1641.

-36 Okada K, Minamino T, Tsukamoto Y, Liao Y, Tsukamoto O, Takashima S, Hirata A, Fujita M, Nagamachi Y, Nakatani T, Yutani C, Ozawa K, Ogawa S, Tomoike H, Hori M, Kitakaze M: Prolonged Endoplasmic Reticulum Stress in Hypertrophic and Failing Heart After Aortic Constriction: Possible Contribution of Endoplasmic Reticulum Stress to Cardiac Myocyte Apoptosis. Circulation 2004;110:705-712.

-37 Azfer A, Niu J, Rogers LM, Adamski FM, Kolattukudy PE: Activation of endoplasmic reticulum stress response during the development of ischemic heart disease. Am J Physiol Heart Circ 2006;291:H1411-H1420.

-38 Hamada H, Suzuki M, Yuasa S, Mimura N, Shinozuka N, Takada Y, Suzuki M, Nishino T, Nakaya H, Koseki $\mathrm{H}$, Aoe T: Dilated cardiomyopathy caused by aberrant endoplasmic reticulum quality control in mutant KDEL receptor transgenicmice. Mol cell Biol 2004;24:8007-8017. 